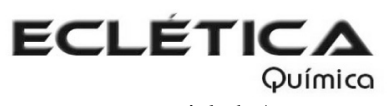

www.scielo.br/eq

Volume 30, número 4, 2005

\title{
Influence of the synthesis conditions on the characteristics and metal adsorption properties of the 3-(1,4-phenylenediamine)propylsilica xerogel
}

\author{
J. C. P. Vaghetti, J. L. Brasil, T. M. H. Costa, E. C. Lima, E.V. Benvenutti * \\ Instituto de Química, UFRGS, CP 15003, 91501-970, Porto Alegre, RS, Brazil. \\ * Corresponding author: e-mail: benvenutti@iq.ufrgs.br
}

\begin{abstract}
The hybrid 3-(1,4-phenylenediamine)propylsilica xerogel was obtained starting from two different organic precursor quantity ( 5 and $8 \mathrm{mmol}$ ) to $22 \mathrm{mmol}$ of TEOS, in the synthesis. The xerogel samples were characterized by using $\mathrm{CHN}$ elemental analysis, $\mathrm{N}_{2}$ adsorption-desorption isotherms, infrared thermal analysis. The xerogel was used as metal sorbent for $\mathrm{Cu}^{2+}, \mathrm{Cd}^{2+}$ and $\mathrm{Pb}^{2+}$ in aqueous solution with concentration range of $10^{-3}$ to $10^{-5} \mathrm{mmol} \mathrm{l}^{-1}$. The quantity of organic precursor added in the synthesis influences the characteristics of the xerogel as morphology and thermal stability, as well as the metal adsorption capacity.
\end{abstract}

Keywords: sol-gel; hybrid powders; pore distribution; morphology; metal adsorbent.

\section{Introduction}

Silica is an inorganic support widely used in many chemical processes aiming several scientific and technical applications [1-5]. This support has been increasingly used because it offers many advantages due for example, its high thermal and chemical stability. In addition, its surface can be easily modified with several organic or inorganic groups. In the last two decades the chemical modification of silica surfaces with organic groups was studied, mainly by using the grafting reactions [6-8]. More recently, hybrid silica based materials, obtained by using sol-gel reactions, have been also studied [9-11]. This synthesis method is attractive due to the possibility to change the physical properties, such porosity, surface area, particle size, etc, by choosing the synthesis conditions $[11,12]$. The sol-gel reactions used to obtain hybrid silica based materials, consist in the hydrolysis and polycondensation of appropriated silicon alkoxides such tetraethylorthosilicate (TEOS) simultaneously with organosilicon derivatives as $\mathrm{R}-\mathrm{Si}\left(\mathrm{OR}^{\prime}\right)_{3}$ where $\mathrm{R}$ is the desired organic group. The mild reaction conditions afford an opportunity to incorporate several organic species by choosing the appropriated reagent. If the organic species present chelating groups, the resulting materials can act as metal chelating sorbents. The possibility of prepare sorbent materials with controlled physical properties, as surface area and pore diameter, allows their use for selective trace metal evaluation in analytical measurements [13-16]. Even so, this method was not extensively explored to obtain metal sorbent materials.

In this work, the 3-(1,4phenylenediamine)propylsilica was obtained by the sol-gel reaction. Changes in the physical properties were attained by varying the organic/inorganic precursor ratio, in the synthesis. The organic grade incorporation, the thermal stability and the resulting porosity of the hybrid xerogels were studied by using infrared thermal analysis and $\mathrm{N}_{2}$ adsorption desorption isotherms. The hybrid xerogels were used as metal adsorbents for divalent copper, cadmium and lead ions in aqueous medium. The metal determination was carried out by visible spectrophotometry. 


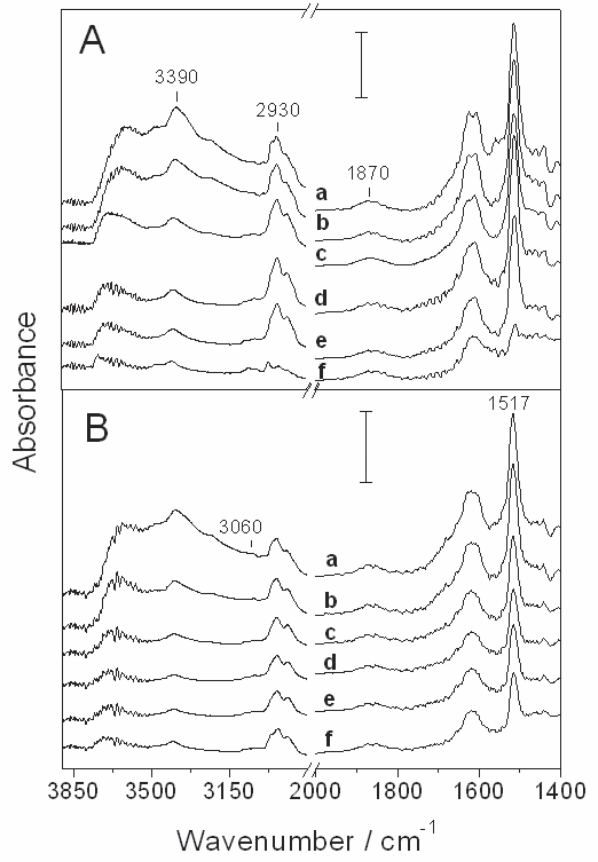

Figure 1: FTIR absorbance spectra for xerogel samples A and $\mathrm{B}$, obtained at room temperature, after heating in vacuum, for 1 hours at: a) 100 , b) 200 , c) 300 , d) 350 , e) 400 and $\mathrm{f}$ ) $450{ }^{\circ} \mathrm{C}$. The bar value is 0.2 for both samples.

\section{Experimental}

\section{Sol-gel synthesis}

The 1,4-phenylenediamine was activated with sodium hydride (Acros) in $10 \mathrm{ml}$ of aprotic solvents mixture (toluene:thf) (1:1) (Merck) for 30 minutes, and 3-chloropropyltrimethoxysilane (CPTMS, Merck,) was added. The quantities used were stoichiometric, 5 and $8 \mathrm{mmol}$ for the synthesis $\mathrm{A}$ and $\mathrm{B}$, respectively. The mixtures were stirred under argon at solvent-reflux temperature for a period of 5 hours. The solutions were then centrifuged, and the supernatants that contain the 3-(1,4-phenylenediamine)propyl trimethoxysilane were used as sol-gel organic precursors in the gelation process. Afterwards, tetraethylorthosilicate (TEOS, Acros) (5 ml), ethyl alcohol (5 ml, Merck), $\mathrm{HF} 40 \%$ (0.1 ml, Synth) and water in stoichiometric ratio with $\mathrm{Si} \mathrm{r}=4 / 1(1.6 \mathrm{ml})$, were added to each organic precursor solutions, under stirring. The gelation occurs by a fluoride nucleofilic catalytic process, at $\mathrm{pH}$ between 8 and 9 . The mixtures were stored for a week, just covered without sealing, for gelation and solvent evaporation. The obtained materials were extensively washed using the solvents: toluene, thf, dichloromethane, ethyl alcohol, distilled water and ethyl ether. The xerogel materials were finally dried for 30 minutes in an oven at $100{ }^{\circ} \mathrm{C}$. The resulting xerogel powders were designated as samples A and B.

\section{Elemental Analysis}

The organic phase contents were obtained using a CHN Perkin Elmer M CHNS/O Analyzer, model 2400 . The analyses were made in triplicate, after heating the materials at $100{ }^{\circ} \mathrm{C}$, under vacuum, for 1 hour.

\section{Pore size distribution}

The pore size distribution was obtained by the $\mathrm{N}_{2}$ adsorption-desorption isotherms, determined at liquid nitrogen boiling point, using a homemade volumetric apparatus, connected to turbo molecular Edwards vacuum line system, employing a $\mathrm{Hg}$ capillary barometer for the pressure measurements. The apparatus is frequently checked with alumina standard reference. The hybrid materials were previously degassed at $150{ }^{\circ} \mathrm{C}$, in vacuum, for $2 \mathrm{~h}$.

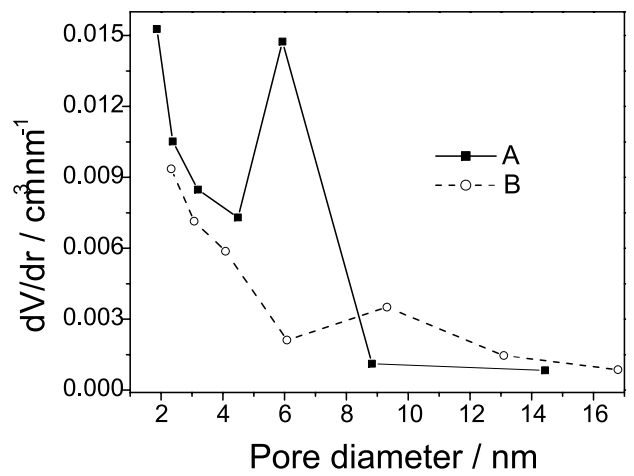

Figure 2: Pore size distribution of xerogel samples $A$ and $\mathrm{B}$, obtained by using BJH method. 


\begin{tabular}{|c|c|c|c|}
\hline Sample & $\begin{array}{c}\text { Organic } \\
\text { precursor added } \\
\mathrm{mmol}\end{array}$ & $\begin{array}{c}\text { Elemental } \\
\text { analysis } \\
\mathrm{mmol} \mathrm{g}^{-1} \mathrm{a}\end{array}$ & $\begin{array}{c}\text { BET Surface } \\
\text { área } \\
\mathrm{m}^{2} \mathrm{~g}^{-1}\end{array}$ \\
\hline $\mathrm{A}$ & 5 & 0.6 & 180 \\
\hline $\mathrm{B}$ & 8 & 0.5 & 150 \\
\hline
\end{tabular}

a mmol de organic groups per gram of xerogel, obtained from $\mathrm{CHN}$ analysis.

Table 1: Elemental analysis and surface area of the obtained xerogels.

\section{Surface Area}

The specific surface area of the previous degassed solid at $150{ }^{\circ} \mathrm{C}$, under vacuum, was determined by the BET multipoint technique in the volumetric apparatus, cited above, using nitrogen as probe.

\section{Infrared measurements}

Self-supporting disks of the xerogels, with an area of $5 \mathrm{~cm}^{2}$, weighing $c a .100 \mathrm{mg}$, were prepared. The disks were heated for 1 hour to temperature ranging from 100 to $450^{\circ} \mathrm{C}$, under vacuum $\left(10^{-2}\right.$ Torr $)$, using an IR cell [17]. The disks were analyzed in the infrared region using a Shimadzu FTIR, model 8300. The spectra were obtained with a resolution of 4 $\mathrm{cm}^{-1}$, with 100 scans.

The infrared thermal analysis is a very effective tool to investigate the presence and the distribution of the organic phase in hybrid xerogel materials with covalent organic-inorganic interface. The analysis is based on the evolution of the infrared band areas of the organics in relation to the thermal treatment [17]. The organics dispersed in opened pores are completely desorbed when heat treated up to $450{ }^{\circ} \mathrm{C}$, in vacuum. However, the remaining organic bands, that not vanish, are attributed to trapped organics in closed pores. Thus, it is possible to calculate the relative organic coverage $i e$. organic groups that are really on the surface, in opened pores. This is obtained subtracting the band area corresponding to the organic trapped groups from band areas of the organic total content. The organic band area values are obtained by using the overtone silica band at ca. 1870

$\mathrm{cm}^{-1}$ as a reference band. This normalization was necessary, considering the heterogeneity in the disks thickness and taking into account the position changes of the infrared beam.

\section{Pre-concentration procedure}

A $5.00 \mathrm{ml}$ of solution containing individually $\mathrm{Cd}^{2+}\left(8.9010^{-6}-3.1110^{-3} \mathrm{~mol} \mathrm{l}^{-1}\right), \mathrm{Cu}^{2+}\left(1.57 .10^{-5}-\right.$ 1.57.10-2 $\left.\mathrm{mol} \mathrm{l}^{-1}\right)$, and $\mathrm{Pb}^{2+}\left(4.83 .10^{-6}-4.83 .10^{-3} \mathrm{moll}^{-}\right.$ $\left.{ }^{1}\right)$ solution plus $20.0 \mathrm{ml}$ of $\mathrm{NaCH}_{3} \mathrm{CO}_{2}-\mathrm{HCH}_{3} \mathrm{CO}_{2}$ buffer solution ( $\mathrm{pH}$ 5.1) were transferred to a $50 \mathrm{ml}$ conical polyethylene flask containing $20.00 \pm 0.09$ $\mathrm{mg}$ of hybrid xerogel sorbent. The system was putted in a horizontal shaker (360 $\mathrm{min}$ ) in order to concentrate the analytes. Subsequently, the solid phase was separated from aqueous phase by filtration, being the aqueous phase retained for analysis.

The elements, which were not retained in the xerogel sorbent, were spectrophotometrically determined. The elements $\mathrm{Cd}^{2+}$ and $\mathrm{Pb}^{2+}$ were determined using 4-(2-pyridylazo)-resorcinol (PAR,

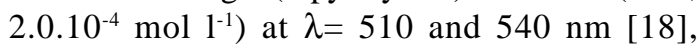
respectively, and $\mathrm{Cu}^{2+}$ was determined using sodium diethyldithiocarbamate (DDTC, 8.9.10-3 $\mathrm{mol} \mathrm{l}^{-1}$ ) [19] using an FEMTO $600 \mathrm{~S}$ spectrophotometer, according to the following procedure: an aliquot of $500 \mu \mathrm{l}$ of aqueous phase and/or analyte standard

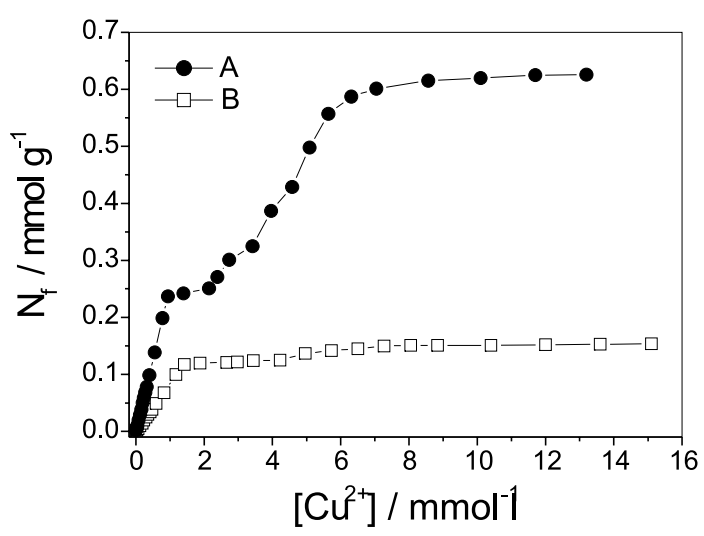

Figure 3: Metal ion adsorption isotherms of xerogel samples $\mathrm{A}$ and $\mathrm{B}$, obtained at $25^{\circ} \mathrm{C}$, in aqueous solution for $\mathrm{Cu}^{2+}$. 


\begin{tabular}{|c|c|c|c|c|c|}
\hline Sample & $\begin{array}{c}\text { Organic } \\
\text { coverage / \% }\end{array}$ & $\begin{array}{c}\text { Available sites } \\
\mathrm{mmol} \mathrm{g}^{-1}\end{array}$ & $\begin{array}{c}\mathrm{Cu} \text { (II) } \\
\mathrm{mmol} \mathrm{g}^{-1}\end{array}$ & $\begin{array}{c}\mathrm{Cd} \text { (II) } \\
\mathrm{mmol} \mathrm{g}^{-1} \mathrm{a}\end{array}$ & $\begin{array}{c}\mathrm{Pb} \text { (II) } \\
\mathrm{mmol} \mathrm{g}^{-1} \mathrm{a}\end{array}$ \\
\hline $\mathrm{A}$ & 89 & 0.53 & 0.62 & 0.31 & 0.40 \\
\hline $\mathrm{B}$ & 65 & 0.33 & 0.15 & 0.11 & 0.17 \\
\hline
\end{tabular}

$\mathrm{a}=$ mmol of metal adsorbed per gram of xerogel.

Table 2: Metal adsorption capacities $\left(\mathrm{N}_{\mathrm{f}}\right)$ of the xerogel samples.

solution plus $1000 \mu \mathrm{l}$ of $0.25 \mathrm{~mol} \mathrm{l}^{-1} \mathrm{Na}_{2} \mathrm{~B}_{4} \mathrm{O}_{7}-0.07$ $\mathrm{mol} \mathrm{l}^{-1} \mathrm{HNO}_{3}$ (pH 9.1) plus $500 \mu \mathrm{l}$ of chromogenic reagent were added to a Hellma glass curvette (10 $\mathrm{mm}$ of optical path). The analyte solutions with concentration higher than those cited above were properly diluted with distilled water. The metal ion adsorption capacity of the solid phase $\left(\mathrm{N}_{\mathrm{f}}\right)$, obtained in the saturation plateau, was calculated by applying the equation $\mathrm{N}_{\mathrm{f}}=\left(\mathrm{N}_{\mathrm{a}}-\mathrm{N}_{\mathrm{s}}\right) / \mathrm{m}$, where $\mathrm{N}_{\mathrm{a}}$ is the initial metal quantity added, $\mathrm{N}_{\mathrm{s}}$ is the metal quantity present in the solution, in equilibrium with the solid phase, and $\mathrm{m}$ is the weight of the solid phase.

\section{Results}

Two samples of hybrid xerogels were obtained and their CHN elemental analysis and the surface area results are showed in Table 1. The presence of the organic component of the hybrid materials can be by confirmed by the elemental CHN analysis, which showed 0.6 and $0.5 \mathrm{mmol}$ of organic groups per gram of xerogel for samples A and $\mathrm{B}$ respectively. The sample A presented the higher value for surface area, $180 \mathrm{~m}^{2} \mathrm{~g}^{-1}$.

The immobilization of the 3-(1,4phenylenediamine)propylsilica groups on the matrix surface was also confirmed by the infrared analysis showed in the Figure 1. It can be observed the typical spectra of hybrid material, with both organic and inorganic moieties. The inorganic component can be identified from the typical silica overtone bands at $c a .1870 \mathrm{~cm}^{-1}$ and the silanol stretching bands above $3500 \mathrm{~cm}^{-1}$. The organic phase is clearly identified by the bands at $1517 \mathrm{~cm}^{-1}$ corresponding to the aromatic ring modes, bands at 3060 and $2930 \mathrm{~cm}^{-1}$, are attributed to aromatic and aliphatic $\mathrm{C}-\mathrm{H}$ stretching modes, respectively, and also the N-H stretching at $c a .3390 \mathrm{~cm}^{-1}$ [20]. The presence of the organics in the samples even after heat treated at $300^{\circ} \mathrm{C}$, in vacuum, is an evidence of the high thermal stability of the organic moieties, bonded in the covalent form [17].

The pore size distribution of the xerogel samples are showed in the Figure 2. It can be seen that the sample A presented a large fraction of pores with diameter higher than $4 \mathrm{~nm}$, while in the sample $\mathrm{B}$ the pores presented diameter values lower than 4 nm.

The metal adsorption results for the samples A and B are presented in the Figures 3, 4 and 5, respectively for $\mathrm{Cu}^{2+}, \mathrm{Cd}^{2+}$ and $\mathrm{Pb}^{2+}$. The xerogel sample A showed higher adsorption capacity than xerogel B, for the three studied metals (Table 2), and the best adsorption capacity was attained for copper $0.62 \mathrm{mmol} \mathrm{g}^{-1}$.

\section{Discussion}

Although the organic quantity added during the synthesis was lower for the sample A in relation to the sample $\mathrm{B}$, the final organic content expressed in mmol per gram of xerogel, was 0.6 for A and 0.5 for B. In previous works, it was observed that the organic grade in the final hybrid xerogel was not linear with the organics/TEOS ratio used in the synthesis, and saturation in organic grade was attained [21]. Additionally, the quantity of oligomers formed increases with the organics/ TEOS ratio increasing [22], which causes a major leaching process during the washing with different solvents after the synthesis [23].

In the infrared spectra of the Figure 1 it can be seen that the organic component present thermal stability even after heat treatment in vacuum at $400{ }^{\circ} \mathrm{C}$. Further thermal treatment at $450{ }^{\circ} \mathrm{C}$ causes a decreasing in the organic content mainly visible for sample A. In the Figure 6 is showed a more complete interpretation of these results. Considering that the characteristic band area of the organics is related to the organic content of the 


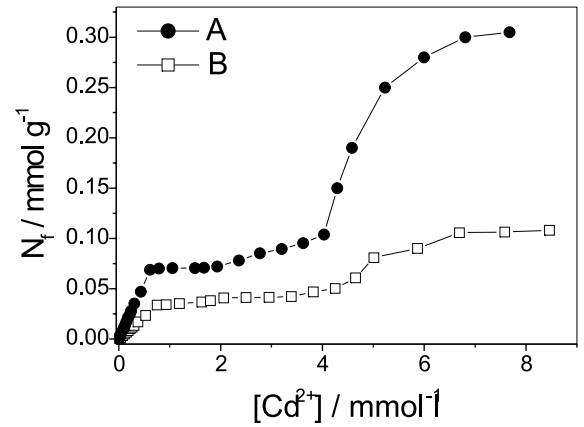

Figure 4: Metal ion adsorption isotherms of xerogel samples $\mathrm{A}$ and $\mathrm{B}$, obtained at $25^{\circ} \mathrm{C}$, in aqueous solution for $\mathrm{Cd}^{2+}$.

sample, it can be seen that samples A and B present a similar organic content, after thermal treatment up to $100^{\circ} \mathrm{C}$, according to $\mathrm{CHN}$ results showed in Table 1 . The better thermal stability was achieved for the sample A, since their remaining organic contents decreased near $25 \%$, after heat treatment up to $400^{\circ} \mathrm{C}$, while for sample B the decreasing was $49 \%$. The marked reduction in the remaining organic grade for the sample B was interpreted taking into account the formation a large quantity of oligomeric species during the synthesis, as above proposed. Further thermal treatment up to $450{ }^{\circ} \mathrm{C}$ produces desorption of all the organic groups from the surface, as observed by the sharp reduction of the remaining organic content for the sample A (Figure 6). After thermal treatment up to $450{ }^{\circ} \mathrm{C}$ the organic groups which cover the surface were completely desorbed, and the remaining band area are due to the organics trapped in closed pores [17]. The trapped organic amount was 11 and $35 \%$, for samples A and B, respectively. Thus, considering the surface organic coverage, the best sample is the A, that has $89 \%$ of the total organics $(0.6 \mathrm{mmol}$ $\mathrm{g}^{-1}$, Table 1), in opened pores, corresponding to $0.53 \mathrm{mmol}$ of available organic groups per gram of xerogel, while sample B presents only $65 \%$ of total organics $\left(0.5 \mathrm{mmol} \mathrm{g}^{-1}\right.$, Table 1$)$ in opened pores, corresponding to only $0.33 \mathrm{mmol}$ of available organic groups per gram of xerogel (Table 2). The larger amount of organics in opened pores for sample $\mathrm{A}$ is in accordance with the pore size distribution analysis presented in Figure 2, which shows a higher porosity for this sample.

The adsorption capacity behavior showed in Table 2 can be explained by the samples features

Ecl. Quím., São Paulo, 30(4): 43-49, 2005 discussed above. The sample A really presents the best characteristics to be used as metal adsorbent since it presents a higher surface area, a proper pore size distribution and a larger surface organic coverage.

The isotherm curves (Figures 3-5) present some characteristics that deserve to be discussed. In a general way the isotherms were similar to the subgroup 4-L type [24], where the sorbent presents a second surface that can be formed during the adsorption process. In present situation, the organic moiety has two chelating sites per pendant group with different steric availability, as represented in the scheme 1 . Additionally we have to consider the morphological effects since the samples present a large fraction of small pores with diameter lower than $3 \mathrm{~nm}$, which could make important diffusion effects for both sites, mainly in the low metal ion concentration. All these features can explain the differences between the isotherm plateaus, i.e. the value of the adsorption capacity for the second isotherm plateau was not twice the first one.

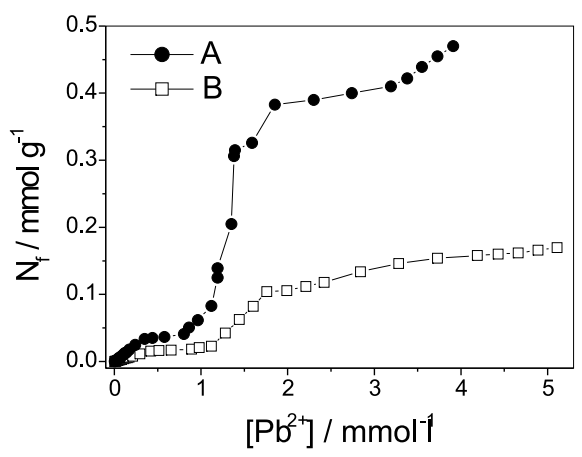

Figure 5: Metal ion adsorption isotherms of xerogel samples $\mathrm{A}$ and $\mathrm{B}$, obtained at $25{ }^{\circ} \mathrm{C}$, in aqueous solution for $\mathrm{Pb}^{2+}$.

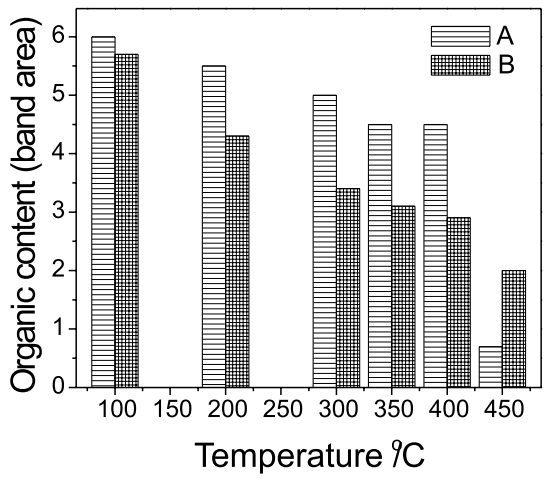

Figure 6: Relative remaining organic content of the xerogel samples A and B calculated from the band areas of the infrared ring mode at $1517 \mathrm{~cm}^{-1}$, after thermal treatment at each temperature. 


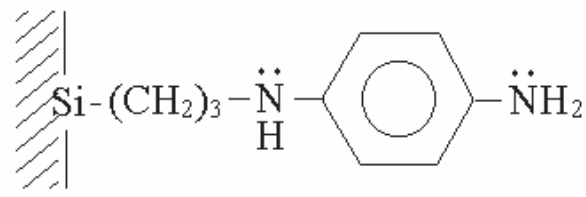

\section{Conclusions}

The hybrid 3-(1,4phenylenediamine)propylsilica xerogel was prepared adding two different quantities of organic precursor, 5 and $8 \mathrm{mmol}$ per $22 \mathrm{mmol}$ of TEOS, samples A and $\mathrm{B}$, respectively. However the final organic content was similar for both, 0.6 (A) and 0.5 (B) $\mathrm{mmol} \mathrm{g}^{-1}$ of xerogel. The sample A presented a higher thermal stability, surface area and porosity. On the other hand, the lower final organic content and lower thermal stability of the sample B was interpreted considering the formation of oligomeric species during the synthesis. The sample A showed a lower fraction of organics occluded in closed pores, and consequently high organic coverage, i.e. organics

in the surface. These characteristics influenced markedly the metal adsorption capacity, making the sample A better metal adsorbent.

\section{Acknowledgements}

We thank to FAPERGS (Fundação de Amparo à Pesquisa no Estado do Rio Grande do Sul) and CNPq (Conselho Nacional de Desenvolvimento Científico e Tecnológico, Brasil), for fellowship and financial support.

Recebido em: 14/09/2005

Aceito em: 04/11/2005

J. C. P. Vaghetti, J. L. Brasil, T. M. H. Costa, E. C. Lima, E. V. Benvenutti. Influência das condições de síntese nas características e nas propriedades de adsorção de metais do xerogel 3-(1,4fenilenodiamina)propilsílica.

Resumo: O xerogel híbrido 3-(1,4-fenilenodiamina)propilsílica foi obtido partindo-se de duas quantidades de precursor orgânico (5 e $8 \mathrm{mmol}$ ) para $22 \mathrm{mmol}$ de TEOS, na síntese. As amostras dos xerogéis foram caracterizadas usando-se análise elementar $\mathrm{CHN}$, isotermas de adsorção e dessorção de $\mathrm{N}_{2}$ e termoanálise

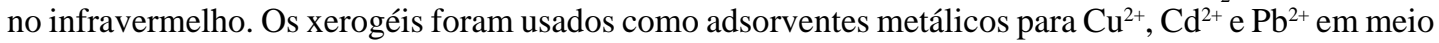
aquoso, na faixa de concentração de $10^{-3}$ até $10^{-5} \mathrm{mmol}^{-1}$. A quantidade de precursor orgânico adicionado na síntese influencia nas características do xerogel como morfologia e estabilidade térmica, como também na sua capacidade de adsorção de metais.

Palavras-chave: sol-gel; pós híbridos; distribuição de poros; morfologia; adsorvente metálico.

\section{References}

[1]. A. Vinu, K. Z. Hossain, K. Ariga, J. Nanosci. Nanotechnol. 5(3) (2005) 347.

[2]. G. Schottner, Chem. Mater. 13(10) (2001) 3422.

[3]. H. -H. Yang, S. -Q. Zhang, W. Yang, X. -L. Chen, Z. X. Zhuang, J. -G. Xu, X. -R. Wang, J. Am. Chem. Soc. 126(13) (2004) 4054.

[4]. C. Sanchez, B. Lebeau, F. Chaput, J. P. Boilot, Adv. Mater. 15(23) (2003) 1969.

[5]. B. Boury, R. Corriu, Adv. Mater. 12(2) (2003) 120.
[6]. F. V.de Moraes, I. L. de Alcântara, P. dos S. Roldan, G. R. de Castro, M. A. L. Margionte, P. de M. Padilha, Eclet. Quim. 28(1) (2003) 9.

[7]. U. Deschler, P. Kleinschmit, P. Panster, Angew. Chem. Int. Ed. Engl. 25(3) (1986) 236.

[8]. P. K. Jal, S. Patel, B. Mishra, Talanta 62(5) ( 2004) 1005 .

[9]. K. J. Shea, D. A. Loy, Chem. Mater. 13(10) (2001) 3306. 
[10].Y. Khoroshevskiy, S. Korneev, S. Myerniy, Y. V. Kholin,

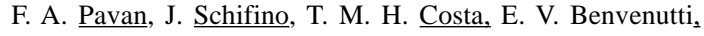
J. Colloid Interface Sci. 284(2) (2005) 424.

[11]. D. R. Azolin, C. C. Moro, T. M. H. Costa, E. V. Benvenutti, J. Non-Cryst. Solids 337(3) (2004) 201.

[12]. L. T. Arenas, J. C. P. Vaghetti, E. C. Lima, C. C. Moro, E. V. Benvenutti, T. M. H. Costa, Mater. Lett. 58(6) (2004) 895.

[13]. J. Brown, L. Mercier, T. J. Pinnavaia, Chem. Commun. (1) (1999) 69.

[14]. F. A. Pavan, A. M. S. Lucho, R. S. Gonçalves, T. M. H. Costa, E. V. Benvenutti, J. Colloid Interface Sci. 263(2) (2003) 688.

[15]. Y. -K. Lu, X. -P. Yan, Anal. Chem. 76(2) (2004) 453. [16]. F. A. Pavan, T. M. H. Costa, E. V. Benvenutti, R. A. Jacques, M. C. Córdova, Quim. Nova 27(5) (2004) 730.
[17]. F. A. Pavan, S. A. Gobbi, T. M. H. Costa, E. V. Benvenutti, J. Therm. Anal. Calorim. 68(1) (2002) 199. [18]. E. Y. Hashem, Spectrochim. Acta Part A 58(7) (2002) 1401.

[19]. R. J. Cassella, Microchem. J. 72(1) (2002) 17.

[20]. J. C. P Vaghetti, M. Zat, K. R. S. Bentes, L. S. Ferreira, E. V. Benvenutti, E. C. Lima, J. Anal. At. Spectrom. 18(4) (2003) 376.

[21]. F. A. Pavan, L. Franken, C. A. Moreira, Y. Gushikem, T. M. H. Costa, E. V. Benvenutti, J. Colloid Interface Sci. 241(2) (2001) 413.

[22]. L. T. Arenas, A. Langaro, Y. Gushikem, C. C. Moro, E. V. Benvenutti, T. M. H. Costa, J. Sol-Gel Sci. Technol. 28(1) (2003) 51.

[23]. L. Franken, L. S. Santos, E. B. Caramão, T. M. H. Costa, E. V. Benvenutti, Quim. Nova 25(4) (2002) 563.

[24]. C. H. Giles, T. H. Macewan, S. N. Nakhwa, D. Smith, J. Chem. Soc. (1960) 3973. 